\title{
Article
}

\section{Micro-Organic Ion-Associate Phase Extraction via in situ Fresh Phase Formation for Preconcentration and Determination of Trace Analytes in Environmental Waters.}

\author{
Noriko HATA, Issei KASAHARA and Shigeru TAGUCHI \\ Department of Environmental Biology and Chemistry, Faculty of Science, Toyama University, 3190 Gofuku, \\ Toyama 930-8555, Japan
}

(Manuscript submitted February 15, 2003; accepted March 31, 2003)

\begin{abstract}
High enrichment/determination system was proposed for environmental trace analyses. Micro organic ion-associate phase (IAP) was formed in situ from an aqueous sample. A trace analyte converted into hydrophobic species or an originally hydrophobic trace analyte was extracted into the IAP quantitatively during the phase formation. After being discarded the aqueous phase, the IAP was dissolved with a small volume of solvent, and the analyte in the concentrate was determined by an appropriate instrumental method. This technique was applied to the preconcentration/ determination of ammonia and nitrite by spectrophotometry, di-2-ethylhexyl phthalate by HPLC-UV detection, and cadmium by GFAAS in environmental waters.
\end{abstract}

\section{Introduction}

Solvent extraction and solid phase extraction are very popular as separation techniques for trace analysis. Solvent extraction is, however, hard to attain a high enrichment of the analyte due to its solubility to water. The use of harmful solvent is another disadvantage of this technique. Solid-phase extraction requires a large sample volume to attain a high enrichment. In both extraction methods, the sample solution must be contacted with the sorbent by mechanical mixing or column process. On the other hand, micro organic phase formation method proposed by Igarashi and Yotsuyanagi [1], and Saitoh et al.[2] seems to have high potential for downsizing of a sample solution because of their high enrichment attainability. In this method an organic phase is freshly formed from an aqueous sample solution. This novel technique has following advantages. The first is the downsizing of a sample volume, therefore, reagents and wastes. The second is rapid and efficient collection of trace analytes to the phase during the phase formation without any mechanical mixing process. The third is the use of only one vessel for whole process of the separation. The forth is no use of harmful solvent.

We proposed high enrichment/determination system for trace analyses in environmental waters based on the micro organic phase formation methods.[3] In this system trace analytes were extracted in a micro-organic ion-associate phase (IAP) via in situ fresh phase formation. And the system has been applied for the spectrophotometric determination of nitrite,[4] HPLC-UV determination of di-2-ethylhexyl phthalate (DEHP), an endocrine disruptor, the spectrophotometric determination of ammonia, [5] and GFAAS determination of cadmium 
at their trace levels in environmental water samples.

\section{Experimental}

\subsection{Apparatus}

A Hitachi (Tokyo, Japan) Model U-2001 UV-visible spectrophotometer with quartz cells ( $3 \mathrm{~mm}$ light width, $1 \mathrm{~cm}$ light pass) or glass cells $(1 \mathrm{~mm}$ light width, $1 \mathrm{~cm}$ light pass) was used for measurements of absorption spectra and absorbance.

The chromatographic system consisted of a Jasco MD-1515 Multiwavelength detector, a Jasco PU-980 Intelligent HPLC pump (Tokyo, Japan), and a manual Rheodyne 7725 injection valve(USA) equipped with a $0.020 \mathrm{~cm}^{3}$ loop. ODS-column (ODS $-80 \mathrm{Ts}, 4.6 \mathrm{mmIDx} 25 \mathrm{~cm}$, Tosoh, Tokyo, Japan) was used.

A Hitachi (Tokyo, Japan) Model Z-8000 flame and graphite furnace atomic absorption spectrometer equipped with a Zeeman-effect background corrector and an optical temperature control system (Hitachi Model 180-0342) was used.

\subsection{Procedure}

The four methods proposed are as follows.

Spectrophotometric determination of nitrite $\left(\mathrm{NO}_{2}-\mathrm{N}\right)$. Place $10 \mathrm{~cm}^{3}$ of sample solution containing less than $0.3 \mu \mathrm{g}$ of nitrite-nitrogen $\left(\mathrm{NO}_{2}^{-}-\mathrm{N}\right)$ in a polypropylene centrifuge tube. Add $0.6 \mathrm{~cm}^{3}$ of $0.1 \mathrm{~mol} / \mathrm{L}$ 4-trifluoromethylaniline $\quad(4-\mathrm{ABTF}) / 2 \mathrm{~mol} \quad \mathrm{dm}^{-3} \mathrm{HCl}$ solution, $0.2 \mathrm{~cm}^{3}$ of $0.2 \%$

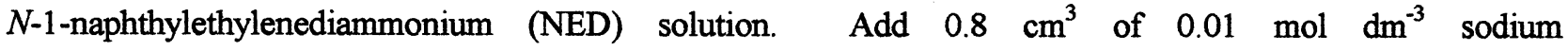
dodecylbenzenesulfonate ( $\mathrm{Na}^{+} \mathrm{DBS}^{-}$, hard type) solution, mix gently and set aside for ten min. Centrifuge at $4500 \mathrm{rpm}$ for $10 \mathrm{~min}$. Discard the aqueous phase. Add $1 \mathrm{~cm}^{3}$ of 2-methoxyethanol and $0.1 \mathrm{~cm}^{3}$ of $4 \mathrm{~mol}$ $\mathrm{dm}^{-3}$ hydrochloric acid to dissolve the IAP. Measure the absorbance due to azo dye at $540 \mathrm{~nm}$ against a reagent blank.

HPLC determination of di-2-ethylhexyl phthalate (DEHP). Place $40 \mathrm{~cm}^{3}$ of sample solution in a glass centrifuge tube. Add $4 \mathrm{~cm}^{3}$ of $0.1 \mathrm{~mol} \mathrm{dm}^{-3} 4-\mathrm{ABTF} / 2 \mathrm{~mol} \mathrm{dm}{ }^{-3} \mathrm{HCl}$ solution. Add $6 \mathrm{~cm}^{3}$ of $0.005 \mathrm{~mol}$ $\mathrm{dm}^{-3}$ sodium dodecylbenzenesulfonate $\left(\mathrm{Na}^{+} \mathrm{DBS}^{-}\right.$, linear type) solution, mix gently and set aside for several min. Centrifuge at $4500 \mathrm{rpm}$ for $40 \mathrm{~min}$. Discard the aqueous phase. Add $0.050 \mathrm{~cm}^{3}$ of 2-methoxyethanol to dissolve the ion-associate phase. Measure the absorbance due to DEHP at about $222 \mathrm{~nm}$ by HPLC/multiwavelength detector.

Spectrophotometric determination of ammonia $\left(\mathrm{NH}_{3}-\mathrm{N}\right)$. Place $4 \mathrm{~cm}^{3}$ of sample solution in a polypropylene centrifuge tube with a plastic screw cap. Add $0.2 \mathrm{~cm}^{3}$ of CDTA/NaOH solution, $0.2 \mathrm{~cm}^{3}$ of buffer solution ( $\mathrm{pH} \mathrm{1)}$ ) and $0.02 \mathrm{~cm}^{3}$ of sodium hypochlorite solution ( $0.3 \%$ available chlorine) $0.25 \mathrm{~cm}^{3}$ of thymol/ $/ \mathrm{NaOH} /$ acetone solution. Set aside for more than $1 \mathrm{~h}$ at $25{ }^{\circ} \mathrm{C}$. Add $0.2 \mathrm{~cm}^{3}$ of $0.1 \mathrm{~mol} \mathrm{dm}^{-3}$ benzethonium chloride solution, mix and set aside for a few min. Centrifuge at $4500 \mathrm{rpm}$ for $10 \mathrm{~min}$. Discard the aqueous phase. Add $1 \mathrm{~cm}^{3}$ of $N, N$-dimethylformamide (DMF) to dilute the IAP. Measure the absorbance due to Indothymol at $675 \mathrm{~nm}$.

GFAAS determination of cadmium. Place $40 \mathrm{~cm}^{3}$ ( $0.02 \mathrm{M}$ Hydrochloric acid) of sample solution in a centrifuge tube. Add $0.4 \mathrm{~cm}^{3}$ of $0.4 \% 5$-Br-PAPS solution. Add $1.6 \mathrm{~cm}^{3}$ of $0.5 \mathrm{~mol} / \mathrm{L}$ sodium phenolsulphonate solution. Add $12.5 \%$ tetramethylammonium hydroxide (TMAH) solution to adjust $\mathrm{pH}$ to 
about 9. Add $0.2 \mathrm{~cm}^{3}$ of $0.1 \mathrm{~mol} \mathrm{dm}$ benzethonium chloride solution. Centrifuge at $4500 \mathrm{rpm}$ for $15 \mathrm{~min}$. Discard the aqueous phase. Dry with microwave irradiation until water evaporate (about $20 \mathrm{~s}$ ). Add 0.075 $\mathrm{cm}^{3}$ of 2-methoxyethanol to dissolve the ion-associate phase. Add $0.025 \mathrm{~cm}^{3}$ of ammonium dihydrogen phosphate / nitric acid solution as a chemical modifier. Inject $0.010 \mathrm{~cm}^{3}$ of the concentrate into the cuvette with a manual and measure the absorption at $228.8 \mathrm{~nm}$ by GFAAS.

\section{Results and discussion}

\subsection{The process of the organic phase formation and extraction of analyte}

Taking the extraction of DEHP as an example, the processes of the formation of the micro-organic ion-associate phase (IAP) and retention of DEHP to the phase are supposed as follows.

First, an organic cation, 4-ABTF ${ }^{+}$, associates with a counter ion, $\mathrm{DBS}^{-}$, to form ion associate, 4-ABTF ${ }^{+} \mathrm{DBS}^{-}$. The ion associate aggregates to form suspension gradually. The centrifugation makes the suspension to a micro-organic IAP.

$$
\begin{aligned}
& \text { 4- } \mathrm{ABTF}^{+} \mathrm{Cl}^{-}+\mathrm{Na}^{+} \mathrm{DBS}^{-} \rightleftharpoons \\
& \mathrm{n} 4-\mathrm{ABTF}^{+} \mathrm{DBS}^{-}+\mathrm{Na}^{+}+\mathrm{Cl}^{-} \\
& \text {(counter ion exchange and ion-pair formation) }
\end{aligned}
$$

During the formation of IAP, a hydrophobic analyte is extracted in the micro-organic IAP.

$$
\mathrm{DEHP}_{\mathrm{aq}} \rightleftharpoons \text { DEHP }_{\text {IAP }}
$$

(3) (distribution of DEHP)

As shown in this example, hydrophobic analytes are separated from hydrophilic compounds in an aqueous solution.

\subsection{Details of the proposed micro organic IAP extraction methods}

The details of the proposed methods and the chemical formula related to the proposed methods are summerized in Table 1. The micro organic IAP extraction methods have some attractive points as a separation technique for trace analysis. The first one is downsizing of the volumes of sample solution, final concentrate and waste. The second one is no use of toxic organic solvent. The third one is very high enrichment factor attainability. And the fourth one is simplicity and rapidity of the separation procedure.

Table 1 List of the proposed methods

\begin{tabular}{|l|c|c|c|c|}
\hline \multicolumn{2}{|c|}{ Analyte } & $\begin{array}{c}\text { Nitrite ion, } \\
\mathrm{NO}_{2}^{-}\end{array}$ & $\begin{array}{c}\text { Di-2-ethylhexyl } \\
\text { phthalate }\end{array}$ & \begin{tabular}{c} 
Ammonia, \\
\hline $\begin{array}{l}\text { Conversion to } \\
\text { proper chemical } \\
\text { species }\end{array}$
\end{tabular} \\
$\begin{array}{l}\text { ion pair of azo dye } \\
\text { cation with counter ion }\end{array}$ \\
$\begin{array}{l}\text { Ion } \\
\text { associate } \\
\text { phase }\end{array}$
\end{tabular}




\begin{tabular}{|l|c|c|c|c|}
\hline $\begin{array}{l}\text { Volume of } \\
\text { concentrate }\end{array}$ & $0.010 \mathrm{~cm}^{3}$ & about $0.025 \mathrm{~cm}^{3}$ & $0.030 \mathrm{~cm}^{3}$ & $0.002 \mathrm{~cm}^{3}$ \\
\hline Enrichment factor & 1000 & 1600 & 130 & 20000 \\
\hline $\begin{array}{l}\text { Organic solvent for } \\
\text { dilution }\end{array}$ & 2-methoxyethnol & 2-methoxyethnol & DMF & 2-methoxyethnol \\
\hline $\begin{array}{l}\text { Final volume for } \\
\text { measurement }\end{array}$ & 1.1 or $0.22 \mathrm{~cm}^{3}$ & about $0.08 \mathrm{~cm}^{3}$ & $1 \mathrm{~cm}^{3}$ & $0.100 \mathrm{~cm}^{3}$ \\
\hline $\begin{array}{l}\text { Enrichment factor } \\
\text { after dilution }\end{array}$ & 10 or 50 & $>500$ & 4 & 400 \\
\hline Determination range & $1.5-30 \mu \mathrm{g} \mathrm{dm}^{-3}$ & $6-78 \mu \mathrm{g} \mathrm{dm}^{-3}$ & $5-100 \mu \mathrm{g} \mathrm{dm}^{-3}$ & $0.5-15 \mathrm{ng} \mathrm{dm}^{-3}$ \\
\hline Dection limits & $0.1 \mu \mathrm{g} \mathrm{dm}^{-3}$ & $0.6 \mu \mathrm{g} \mathrm{dm}$ \\
\hline $\begin{array}{l}\text { Method of } \\
\text { measurement }\end{array}$ & Spectrophotometry & $\begin{array}{c}\text { HPLC/UV } \\
\text { detection }\end{array}$ & Spectrophotometry & GFAAS \\
\hline
\end{tabular}

\subsection{Application of the proposed methods to environmental water samples}

Table 2 shows the analytical results for nitrite, DEHP, ammonia and cadmium concentration in environmental waters. $\mathrm{NH}_{3}-\mathrm{N}$, which is discharged from various sources such as household wastewater, fertilizers, tobacco smoke and natural background, is detected in relatively clean water sample. However, DEHP was detected in the polluted river water such as Furu River discharged household wastewater.

Table 2 Application to river water samples for nitrite $\left(\mathrm{NO}_{2}-\mathrm{N}\right)$, di-2-ethylhexyl phthalate (DEHP), ammonia $\left(\mathrm{NH}_{3}-\mathbf{N}\right)$, and cadmium (Cd). Mean \pm standard deviation.

\begin{tabular}{|c|c|c|c|c|c|}
\hline & Sample & $\begin{array}{l}\text { Nitrite ion, } \\
\mu \mathrm{g} \mathrm{NO}_{2}-\mathrm{N} \mathrm{dm}^{-3}\end{array}$ & $\begin{array}{c}\text { DEHP } \\
\mu \mathrm{g} \mathrm{dm}^{-3}\end{array}$ & $\begin{array}{c}\text { Ammonia, } \\
\mu \mathrm{g} \mathrm{NH}_{3}-\mathrm{N} \mathrm{dm}^{-3}\end{array}$ & $\begin{array}{c}\text { Cadmium } \\
\mathrm{ng} \mathrm{dm}^{-3}\end{array}$ \\
\hline \multirow[t]{3}{*}{ River water } & Sho River ${ }^{\mathrm{a}}$ & $1.9 \pm 0.1$ & -- & $9 \pm 0.7$ & - \\
\hline & Jindzu River ${ }^{b}$ & $8.5 \pm 0.2$ & $<0.6$ & - & $10.9 \pm 0.4^{\mathrm{c}}$ \\
\hline & Furu River $^{d}$ & - & $15.1 \pm 0.6$ & $132 \pm 2^{\mathrm{e}}$ & $7.0 \pm 0.2$ \\
\hline \multirow[t]{2}{*}{ Sea water } & Yokata Fishing Port $\mathrm{f}^{\mathrm{f}}$ & $4.1 \pm 0.1$ & $\cdots$ & - & $\cdots$ \\
\hline & Namerikawa offshore $^{f}$ & - & - & -- & $10.2 \pm 0.4^{\mathrm{c}}$ \\
\hline
\end{tabular}

a. Running on the countryside and town area (the middle reaches), $b$. running on the countryside (the middle reaches), c. 100-fold concentration, d. running on the town area, a branch of Jindzu River, e. 2.5-fold concentration, and $f$. in the Toyama Bay.

These micro-organic ion-associate phase extraction methods were successfully applied to the spectrophotometric determination of trace ammonia and nitrite, HPLC/UV detection of DEHP, and GFAAS determination of cadmium in environmental waters. Downsizing of a sample volume in these methods is effective for reducing reagents and waste.

\section{References}

1) S. Igarashi and T. Yotsuyanagi, Mikrochim. Acta, 106, 37-44 (1992).

2) T. Saitoh, T. Ohyama, K. Takamura, T. Sakurai, T. Kaise and C. Matsubara, Anal. Sci., 13, 1-4 (1997).

3) N. Hata, K. Ando, M. Kawashima, I. Kasahara and S. Taguchi, Anal. Sci., 17(Supplement), i1215-1218 (2001).

4) N. Hata, M. Kawashima, I. Kasahara and S. Taguchi, Anal. Sci., 19(2), 239-243(2003).

5) N. Hata, I. Kasahara and S. Taguchi, Anal. Sci., 18(6), 697-699 (2002). 